\title{
SEGATA, Jean; RIFIOTIS, Theophilos (orgs.). 2018. Politicas etnográficas no campo da ciência e das tecnologias da vida. Porto Alegre: ABA Publicações. 188 pp.
}

\author{
FERNANDO JOSÉ CIELLO
}

Politicas Etnográficas no campo da ciência e das tecnologias da vida é uma obra que resulta da atividade conjunta dos grupos de pesquisa GrupCiber (UFSC) e GEMMTE (UFRGS). A coletânea emerge como um dos resultados da quarta edição do Seminário Mapeando Controvérsias Contemporâneas na Antropologia, evento que tem caracterizado os empreendimentos deste coletivo de pesquisas há vários anos e que também tem sido um nódulo importante na solidificação de uma agenda de pesquisas que se volta à reflexão sobre modos de vida, cibercultura e sociabilidade, relações humano-animal, problemas e derivações do conceito da agência e, aqui de modo central, também as relações que envolvem a tecnologia, estudos da ciência e práticas de governo da vida.

Colocado desta forma, fica evidente que os tópicos e, justamente, as controvérsias teóricas e etnográficas que são tocadas pelas pesquisas desse coletivo são diversas e, assim como as pesquisas resultantes das atividades dos grupos, também os artigos da presente obra enunciam a diversidade e complexidade que atravessa este campo de investigações. O livro está dividido em sete capítulos, de autorias diferentes. Cada sessão toca em questões e em universos etnográficos particulares, contribuindo para a ampliação da etnografia como um instrumento potente de reflexão e como uma ferramenta para a compreensão dos modos como entidades distintas contribuem para a constituição de diferentes "fatos".

Esses fatores tornam o livro um espaço importante de conhecimento das múltiplas perspectivas teóricas que atravessam este campo de pesquisas; das práticas etnográficas no campo mais geral da ciência e das tecnologias da vida; e, por fim, também da etnografia, propriamente, que resulta constantemente pensada, questionada, tensionada. Neste sentido, é importante destacar que a expressão politicas etnográficas ganha especial notoriedade dentro desta e de outras obras que nascem dos grupos de pesquisa mencionados, ressaltando justamente "as eleições etnográficas que fundamentam os distintos modos de conduzir e produzir a etnografia” (p. 08). Ainda que não totalmente explorada, a expressão é de importância impar para a antropologia e, neste sentido, também uma contribuição importante não só neste campo específico de debates.

Há na obra, de modo explícito, assim, uma tentativa de contribuir para um projeto mais amplo de "renovação da antropologia", como sugerem os organizadores, a partir do qual se possa não somente 
questionar, mas também deslocar o lugar ocupado pelo ser humano no centro do mundo social (Idem). Ainda que nem todos os textos da coletânea se apropriem de discussões teóricas que se tornaram clássicas dentro deste campo, fica evidente uma forte relação da discussão mais geral do livro com discussões empreendidas por Bruno Latour, Marilyn Strathern, Philippe Descola, Tim Ingold, Eduardo Viveiros de Castro, Isabel Stengers. A cada capítulo, no entanto, fica evidente também a possibilidade de tensionamento com este corpus teórico, assim como o papel central da etnografia não só na evidenciação de redes e modos de relações, mas também de sua existência enquanto prática que ressalta e possibilita a experimentação com essas mesmas multiplicidades. A apresentação dos capítulos nos dará mais direções para refletir sobre o projeto geral que perpassa os investimentos do livro.

O primeiro texto, de autoria de Francisco Pazzarelli, "A vida-fumaça dos montes", avalia o impacto do aparecimento de políticas de desenvolvimento pautadas na ideia de sustentabilidade no contexto das cozinhas e fornos tradicionais na região de Jujuy, Argentina. $\mathrm{O}$ autor se pergunta o que acontece quando surgem tentativas de mudança na estrutura tradicional destas cozinhas e que contornos este encontro possui (pp. 15-16). O texto combina elementos etnográficos, teóricos, e permite um experimento de simetria entre cozinhas tradicionais, projetos nacionais e teoria antropológica. Para o autor, nem sempre a diferença entre dois polos indica contradição ou impossibilidade de coabitação. De um lado, projetos de desenvolvimento buscam minorar efeitos tomados como negativos das cozinhas e fornos tradicionais, especialmente relacionados a irritações nos olhos, presença constante de fumaças e excessos de lenha do modelo tradicional. E, de outro, os habitantes e proprietários destas cozinhas, cuja vida é atravessada pela existência das cozinhas e suas fumaças, os quais em nenhum momento - apesar de sua adesão ao modelo de "fornos econômicos" - deixam de utilizar os fornos tradicionais.

Pazzarelli, ao lançar mão da ideia de "equivocação controlada", de Eduardo Viveiros de Castro, sugere que distante de ser uma situação de diferença irreconciliável, a presença deste equívoco sobre a forma de conceber as fumaças é o modo mesmo por meio do qual as relações se desenrolam. Em outras palavras, a equivocação é um lugar habitado pelas famílias e a existência da própria equivocação garante uma ampliação dos mundos de relações para os quais se abrem cada uma destas realidades. Os fornos tradicionais, produtores de muita fumaça, permanecem sendo usados pelas famílias, mas a instalação da política e dos novos fornos, acaba também indicando a possibilidade de multiplicar opções culinárias, possivelmente potencializando o próprio sentido ali intrínseco da relação existente entre as cozinhas, as fumaças, o ambiente de Jujuy e a alimentação.

Da Argentina seguimos para o Rio Grande do Sul, no Brasil, contexto sobre o qual repousa a reflexão de Claudia Fonseca, "Deslocando o gene: o DNA entre outras tecnologias de identificação familiar". No texto a autora realiza três movimentos narrativos centrais, que buscam evidenciar como o terreno da identificação familiar avançou desde um momento antes do uso de testes, passando pela implantação e uso limitado de exames de sangue, até um momento mais contemporâneo onde o exame de DNA parece ter se tornado prática central de reconhecimento familiar. A autora questiona a hipótese da "genetização", permitindo problematizar a presença hegemônica do discurso biomédico na determinação das vidas das pessoas envolvidas. Contrapondo-se a isso, vamos ver que o deslocamento 
do uso e modelos tecnológicos é constantemente acompanhado por agentes que praticam e agenciam estes conceitos e tecnologias.

O trabalho mostra não somente a "evolução" de práticas específicas neste campo, mas de modo muito perspicaz, também o modo como tecnologia - enquanto fenômeno e categoria - vai sendo desdobrada de distintas maneiras, ao mesmo tempo em que ela própria também vai sendo constituída e agenciada. Por sua vez, o uso das tecnologias de identificação impacta não somente o campo jurídico, mas a própria organização familiar e de parentesco, que resulta evidentemente transformada deste processo de relação com as tecnologias, as quais por sua vez também se conectam e também transformam o próprio modo pelo qual a justiça opera e percebe relações a partir destas mesmas tecnologias.

O terceiro texto da coletânea, de autoria de Jean Segata, "Infraestruturas globais, práticas locais: o Aedes aegypti e o digital", está focado de modo mais central numa articulação com o elemento não-humano, especialmente no fato de que políticas de controle e vigilância de epidemias por Aedes aegypti têm sido cada vez mais pensadas a partir da inovação digital, drones e mudanças genéticas (p. 61). Segata apresenta uma etnografia das práticas de agentes de endemias em uma capital do Nordeste brasileiro, com notada atenção para o uso do aplicativoVigi@dengue.

Como os artigos anteriores, há uma constante apresentação das redes e dobras que envolvem, nesse caso, agentes de endemias, mosquitos e instrumentos tecnológicos. Ao passo que o aplicativo acaba definindo um modo de organização do espaço e da percepção da cidade e dos focos de mosquitos, também o Aedes aegypti resulta como uma entidade que serve para a criação de outras redes, dentre elas os próprios empregos - "sem mosquito, sem dinheiro" (p. 79) - e também das intrincadas relações entre os agentes de endemias e entre estes e a população, assim como da população para com o mosquito e o Estado. Estes contrastes contribuem para uma maior compreensão do tipo de redes que se estabelecem com o mosquito da dengue e como elas também desdobram outras relações, que impactam entre outras coisas também a população de mosquitos e seus hábitos. Outro argumento central, neste sentido, é o que busca compreender como a política pública acaba responsabilizando a população e, simultaneamente, também desincumbindo-se do papel de prover melhores condições sanitárias.

Como quarto capítulo, temos o trabalho de Carlos Emanuel Sautchuk, "Os antropólogos e a domesticação: derivaçôes e ressurgência de um conceito" e, em seguida, a reflexão de Iara Maria de Almeida Souza e Miriam Cristina Rabelo, "Agência: para além da oposiz̧ão entre atividade e passividade".

$\mathrm{O}$ artigo de Sautchuk tem como principal mote revisitar a categoria da domesticação tendo em vista sua ressurgência no campo da antropologia em tempos mais recentes. $\mathrm{O}$ autor o faz principalmente a partir de trabalhos mais jovens de Tim Ingold e da releitura de autores associados com a antropologia da técnica francesa da década de 1980. O capítulo tem viés mais teórico que os demais e busca ressaltar, a partir da leitura de diferentes tradições de pesquisa, a importância que a categoria tem para a antropologia: precisamente sua indefinição, ambiguidade e maleabilidade. Sautchuk investe neste lugar de instabilidade da "domesticação" como produtivo para a antropologia. Um retorno a estes diferentes usos e controvérsias poderia indicar avanços na crítica à distinção natureza-cultura, bem como uma ampliação do escopo destes estudos para além do par humano-animal e da reificação da categoria biológica de "espécie". 
O capítulo de Souza e Rabelo, por sua vez, apresenta duas experiências etnográficas distintas: o processo de feitura no santo de Rosinha, que é tomada por diferentes orixás e entidades e que acaba sendo reclamada por Iansã, no contexto do Candomblé; e, Deraldo, apaixonado por animais e técnico em um biotério, que descreve sua forma de compreender e ser compreendido pelos hamsters do laboratório. O ponto central do artigo repousa em uma torção da noção de agência clássica, a qual é frequentemente pensada em termos de sua oposição com ideias de atividade e resistência e que, nesses termos, não dá conta do que acontece com Rosinha e Deraldo, dado que em ambos os contextos a docilização e a sujeição constituem processos centrais de fabricação de agentes/sujeitos.

As autoras rearticulam sua proposição a partir das reflexões de Saba Mahmood e Isabel Stengers, para ressaltar que o conceito de agência está assentado em uma concepção liberal de sujeito e que é necessário um modelo que ressalte como o ser agente é praticado e pensado pelas pessoas, ao mesmo tempo em que se articule também os modos por meio dos quais as entidades são levadas a se conectar, sem pressupor princípios de atividade, obrigação ou passividade nas relações.

O texto seguinte, de autoria de Fabiola Rohden, "Considerações teórico-metodológicas sobre objetos instáveis e ausências presentes: analisando processos de materialização do desejo feminino" parte de uma pergunta sobre como constantemente o discurso sobre hormônios é utilizado pra justificar ou explicar comportamentos, atribuindo a estes o adjetivo de naturais. Rohden propõe um olhar para as limitações das concepções metodológicas com as quais operamos quando confrontadas com a interrogação em torno de um objeto tão instável quanto os hormônios e, neste sentido, um olhar também para o processo de constituição dos objetos de conhecimento.

A autora busca refletir precisamente sobre a ideia de que o hormônio chamado testosterona tem impacto determinante no desejo feminino, propondo, para tal, não atribuir agência irrestrita para tais substâncias e, ao mesmo tempo, também pensar nos efeitos possíveis de suas agências. As complexas interações entre hormônios e desejo, trazidas a partir de discursos biomédicos e de mulheres que vivenciaram processos de tratamento e consulta, refletem as múltiplas maneiras por meio das quais o discurso dos hormônios materializa realidades na vida das mulheres. A ideia de que mulheres que fazem reposição de hormônios teriam mais desejo acaba se tornando central, fazendo circular não somente o campo da reflexão sobre os hormônios, mas também acentuando a lógica diagnóstica em torno da ausência ou presença de testosterona.

O capítulo final, de autoria de Caetano Sordi e Bernardo Lewgoy, "Javalis no Pampa: invasóes biológicas, abigeato e transformações da paisagem na fronteira brasileiro-uruguaia" parte do mapeamento das controvérsias em torno da promulgação de uma instrução normativa que autorizava a caça de “javalis asselvajados europeus" (gênero Sus scrofa) na região de Santana do Livramento no extremo Sul do país. De maneira geral, o texto percorre pela necessidade de compreensão da complexidade e características da região dos Pampas e analisa como um evento etnográfico específico, envolvendo um embate entre agricultores e 'defensores da causa animal' em razão da instrução da normativa mencionada, indica, de modo metonímico, para outras relações que atravessam a constituição ecológica, social e cultural da região da fronteira com o Uruguai, especialmente tendo em vista as complexas relações que envolvem a própria cultura de fronteira e a questão da propriedade. Como a tônica mais geral do livro, 
também aqui os autores sugerem que a agência dos Javalis não seja pensada somente em termos de sua "invasão biológica" - conceituação debatida também ao longo do texto - mas que seja contrastada com estas características da região onde ela acontece.

Apesar da coletânea não ser dividida em sessões temáticas, parece possível dizer que os três primeiros capítulos se dedicam de modo mais central para discussões relacionadas com a tecnologia, ainda que com diferentes complicadores e atravessamentos. Numa segunda sessão, imaginada aqui para fins de compreensão da obra temos, por sua vez, dois trabalhos que tocam na categoria da domesticação de diferentes formas, trazendo a potência da ambiguidade para a antropologia e da docilidade na produção de agentes. Os dois capítulos finais, por fim, apresentam um diálogo mais próximo com temas do campo da biomedicina e, no último caso, um exemplo das interações entre aspectos ecológicos e políticos. O livro apresenta um conjunto interessante e diversificado de discussões que estão marcadas pela experimentação etnográfica com o tema das multiplicidades. Todos os textos apresentam uma riqueza importante na demonstração do que vários identificaram como "dobras" dos processos analisados, seja na implantação das cozinhas, das práticas em torno de novas tecnologias, seja a partir de diagnósticos e processos biomédicos. Seguindo o que sugerem os organizadores, fica evidente que a importância de pensar a prática antropológica em termos de suas "políticas etnográficas" faz coro com uma busca contemporânea por reconhecer, compreender, tensionar tudo aquilo que é eleito como central para o fazer etnográfico, tentando (re)articular e projetar novas formas de etnografia, atentas a outros modos de relação, regimes de saberes e conhecimentos, agentes e coletivos.

Fernando José Ciello é mestre (UFPR) e doutor (UFSC) em Antropologia Social. Desde 2019 é Professor Adjunto A da Universidade Federal de Roraima (UFRR). 